\title{
Interaction between estrogen receptor and retinol-binding protein-4 polymorphisms as a tool for the selection of prolific pigs
}

\author{
Iara Denise Vasconcellos Gonçalves ${ }^{1}$, Paulo Bayard Dias Gonçalves ${ }^{1}$, Janandra Cortese da Silva ${ }^{1}$, \\ Valério Valdetar Portela $\mathrm{Jr}^{1}$, Luiz Felipe Kruel Borges ${ }^{1}$, João Francisco Coelho Oliveira ${ }^{1}$ \\ and Paulo Alberto Lovatto ${ }^{2}$ \\ ${ }^{1}$ Laboratório de Biotecnologia e Reprodução Animal, Departamento de Clínica de Grandes Animais, \\ Universidade Federal de Santa Maria, Santa Maria, RS, Brazil. \\ ${ }^{2}$ Departamento de Zootecnia, Universidade Federal de Santa Maria, Santa Maria, RS, Brazil.
}

\begin{abstract}
The aim of the present study was to investigate the association of the estrogen receptor (ER-Pvull) and retinolbinding protein 4 (RBP4-Mspl) gene polymorphisms and their interactions with prolificacy in a commercial synthetic pig line reared in Brazil. A total of 10,374 piglet records from 218 sows and 817 litters were used for litter size analysis. Only females with three or four farrowings were included in the analysis. The mean litter size ranged from 5.0 to 19.5 piglets. DNA was extracted from leukocytes by a standard method, and ER-Pvull and RBP4-Mspl polymorphisms were characterized by the polymerase chain reaction-restriction fragment length polymorphism (PCRRFLP) technique. The association between alleles or genotypes and reproductive performance was analyzed using a general linear model including the interaction between the ER-Pvull and RBP4-Mspl genotypes. For the ER-Pvull gene, the allele frequencies of allele $A$ and allele $B$ were 0.56 and 0.44 , respectively. For the RBP4-Mspl gene, the frequencies of alleles $A 1$ and $A 2$ were 0.29 and 0.71 , respectively. The total number of piglets born (TNB), born alive (NBA), or number of mummies and stillborn piglets (NMUM and NSB) per litter did not differ between the various $E R$-Pvull and RBP4-Mspl genotypes. However, when the ER-Pvull and RBP4-Mspl genotypes were considered together in each sow, TNB and NBA were $1.4(p=0.0026)$ and $0.9(p=0.019)$ higher in AA/A1 and AB/A1 animals, respectively, than in AA/A2 and BB/A1 animals. Likewise, TNB and NBA were $0.9(p=0.0258)$ and $0.8(p=0.0168)$ higher in $B B / A 2$ and $A B / A 2$ sows, respectively, than in $A A / A 2$ and $B B / A 1$ animals, but no difference was observed compared to $A A / A 1$ and $A B / A 1$ animals. The results showed larger litter sizes (TNB and NBA) for sows carrying the ER-Pvull allele $\mathrm{A}$ and the RBP4-Mspl genotype $\mathrm{A} 1$, and for animals carrying the ER-Pvull allele $\mathrm{B}$ and the $R B P 4-M s p l$ genotype A2. In conclusion, the interaction between genotypes ER-Pvull and RBP4-Mspl is more efficient in the selection of prolific sows than each one of these molecular markers alone.
\end{abstract}

Key words: swine, marker-assisted selection, retinol-binding protein-4, estrogen receptor.

Received: August 31, 2007; Accepted: December 19, 2007.

\section{Introduction}

The main objective of genetic pig breeding, especially sows, is to increase the production efficiency and the final quality of the product. Animals with a high genetic potential for a set of traits are selected as parents for the next generations. In current selection programs, the prediction of genetic merit of selection candidates is based on the evaluation of traits in the candidate animals themselves or in members of the family (Varona et al., 2005). However, this approach is not ideal when the traits are limited by sex, measured in carcass, or related to reproductive efficiency.

Send correspondence to P.A. Lovatto. Departamento de Zootecnia, Universidade Federal de Santa Maria, Campus Camobi, 97105-900 Santa Maria, RS, Brazil. E-mail: lovatto@ smail.ufsm.br.
Molecular biology techniques allow identifying and characterizing mutations that have occurred during animal evolution (Dekkers, 2004). Due to the recent advances in molecular genetics, marker-assisted selection offers new opportunities for the identification of differences between individuals, both at the genetic and at the phenotypic level (Vidal et al., 2005). Marker-assisted selection combined with conventional methods is particularly interesting for the selection of traits that cannot be assessed in all candidates. In addition, this approach is more efficient in the case of negatively correlated traits. A first step toward this type of selection was taken with the development of highdensity genetic maps. Thus, genetic markers that have been 
correctly associated with important genes can be used in selection programs, providing a substantial genetic gain.

Polymorphisms in genes related to prolificacy and productivity, such as the estrogen receptor polymorphism (ER-PvuII) gene (Rothschild et al., 1996), and to higher embryo survival, such as the retinol-binding protein 4 polymorphism (RBP4-MspI) gene (Rothschild et al., 2000), have been identified as molecular markers for the selection of more prolific animals. These markers were first investigated in Meishan pigs, which produce about four piglets more per litter (Rothschild et al., 1996). Animals carrying the favorable ER-PvuII allele (allele B) produced 1.25 to 1.50 piglets more per litter (Rothschild et al., 1994; Rothschild et al., 1996; Short et al., 1997). In the first studies on the RBP4-MspI polymorphism, animals with the favorable genotype produced about 0.50 more piglets and 0.26 more liveborn piglets per litter than those with the unfavorable genotype (Rothschild et al., 2000). However, studies using these markers for the analysis of other populations were unable to demonstrate an advantage of these genotypes (Drogemuller et al., 2001; Isler et al., 2002; Gibson et al., 2002). In addition, the favorable allele (allele B) of the ER-PvuII polymorphism has not been observed in lines derived from the Duroc and German Landrace breeds (Short et al., 1997; Drogemuller et al., 2001). In parallel, a low frequency of allele B $(0.10)$ was observed in synthetic pig lines from Germany (Drogemuller et al., 2001).

Prolificacy is a multigene trait of low heritability, and an increase in this trait is determined by various factors. Therefore, a single molecular marker will hardly be efficient in the identification of more productive animals in all populations. The hypothesis of the present study was that the interaction between polymorphisms of two candidate genes, $E R$ and $R B P 4$, might represent an alternative for the identification of more prolific animals in a larger number of populations. The aim of the present study was to investigate the association of $E R$ and $R B P 4$ gene polymorphisms and their interactions with prolificacy in a synthetic pig line reared in Brazil.

\section{Material and Methods}

\section{Animals}

A total of 10,374 piglet records from 218 commercial sows belonging to the São Roque farm, municipality of Videira, State of Santa Catarina, and 817 farrowings were analyzed. The animals were selected according to individual history, considering the number of farrowings and prolificacy. Only sows with three or four farrowings were included in the analysis. Based on their mean productivity \pm 2 standard deviations, the animals were classified as being of low, medium or high productivity, and blood was collected for DNA extraction, amplification by PCR and characterization of polymorphisms by RFLP (polymerase chain reaction-restriction fragment length polymorphism - PCRRFLP).

Blood samples were collected by puncture of the jugular vein using an anticoagulant, and genomic DNA was extracted according to the method described by Lahiri and Nurnberger (1991).

For the characterization of the ER-PvuII polymorphism by PCR-RFLP, a 120-bp fragment was amplified by PCR, using the following specific primers described by Short et al. (1997): forward 5'-CCTGTTTTTACAGTGA CTTTTACAGAG-3' and reverse 5'-CACTTCGAGGGT CAGTCCAATTA-G-3'. The reaction mixture contained PCR buffer (200 mM Tris- $\mathrm{HCl}, \mathrm{pH} 8.4,500 \mathrm{mM} \mathrm{KCl})$, $2 \mathrm{mM}$ of each dNTP, $5 \mathrm{mM}$ of each primer, $0.5 \mathrm{U}$ Taq DNA polymerase and $30 \mathrm{ng}$ genomic DNA, in a final volume of $25 \mu \mathrm{L}$. The amplification conditions were: one denaturation cycle at $94{ }^{\circ} \mathrm{C}$ for $3 \mathrm{~min}$, followed by 30 cycles at $94{ }^{\circ} \mathrm{C}$ for $1 \mathrm{~min}, 55^{\circ} \mathrm{C}$ for $45 \mathrm{~s}$ and $72{ }^{\circ} \mathrm{C}$ for $1 \mathrm{~min}$, and a final extension step at $72{ }^{\circ} \mathrm{C}$ for $4 \mathrm{~min}$. The PCR products were digested with PvuII for $2 \mathrm{~h}$ at $37{ }^{\circ} \mathrm{C}$ in a reaction mixture containing $1.6 \mu \mathrm{L}$ ultrapure water, $1.5 \mu \mathrm{L}$ buffer, $1 \mathrm{U}$ of PvuII, and $11.5 \mu \mathrm{L}$ of the amplified product. The digested products were submitted to electrophoresis on $4 \%$ agarose gel containing ethidium bromide at $94 \mathrm{~V}$. The bands were visualized under ultraviolet light, and the size of the fragments was determined by comparison with a known molecular weight marker (100-bp ladder). The results obtained were recorded with an Alpha Digidoc 1000 photodocumentation system (Alpha Innotech Corp., San Leandro, $\mathrm{CA}$ ). The animals were classified as genotype AA, AB or BB.

For the characterization of the RBP4 gene polymorphism by RFLP, a 550-bp fragment was amplified by PCR, using the following specific primers described by Rothschild et al. (2000): forward 5'- GAGCAAGATGG AATGGGTT - 3' and reverse 5'- CTCGGTGTCTGTAA AGGTG -3'. The reaction mixture, in a final volume of $25 \mu \mathrm{L}$, was the same as that used for $E R$-PvuII. The amplification conditions were: one denaturation cycle at $93{ }^{\circ} \mathrm{C}$ for $3 \mathrm{~min}$, followed by 40 cycles at $93{ }^{\circ} \mathrm{C}$ for $30 \mathrm{~s}, 56{ }^{\circ} \mathrm{C}$ for $45 \mathrm{~s}$, and $72{ }^{\circ} \mathrm{C}$ for $45 \mathrm{~s}$, and a final extension step at $72{ }^{\circ} \mathrm{C}$ for 5 min. The PCR products were digested with MspI for $12 \mathrm{~h}$ in a reaction mixture containing $1.6 \mu \mathrm{L}$ ultrapure water, $1.5 \mu \mathrm{L}$ buffer, $1 \mathrm{U}$ MspI, and $11.5 \mu \mathrm{L}$ of the PCR product. The samples were submitted to electrophoresis on $2 \%$ agarose gel containing ethidium bromide at $94 \mathrm{~V}$, and the bands were visualized under ultraviolet light. Fragment size was determined by comparison with a known molecular weight marker (100-bp ladder). The results obtained were recorded with an Alpha Digidoc 1000 photodocumentation system (Alpha Innotech Corp., San Leandro, CA). The two genotypes distinguished as 11 and 22 (Rothschild et al., 2000) were named A1 and A2, respectively. 


\section{Statistical analysis}

The association of alleles ER-PvuII and RBP4-MspI with genotypes and reproductive performance of sows was analyzed according to the following model:

$$
Y_{i j}=\mu+\alpha_{i}+\beta_{j}+(\alpha \beta)_{i j}+\varepsilon_{i j k}
$$

where $Y_{i j}$ is the mean number of piglets born alive (NBA), number of mummies (NMUM), number of stillborn piglets (NSB), or total number born (TNB) per litter, $\mu$ is the common constant to all observations, $\alpha_{i}$ is the effect of genotype, $\beta_{j}$ is the effect of parity, the letters in parenthesis represent the interaction between factors, and $\varepsilon_{i j}$ is the residual effect. The boar effect was not included in the model because the sows were inseminated with pooled doses from several boars. The genotypes and their interactions were compared using the contrast tool of the SAS software. All analyses were carried out with the general linear model (GLM) procedure of the SAS software. Compliance with Hardy-Weinberg equilibrium was evaluated using the GDA program (Lewis and Zaikin, 2001).

\section{Results}

For the ER-PvuII polymorphism, allele frequencies were 0.56 for allele A and 0.44 for allele B. No significant deviation from the Hardy-Weinberg equilibrium was observed for this locus. The frequencies of the ER-PvuII and $R B P 4-M s p I$ genotypes and their interactions are shown in Figures 1 and 2. The mean litter size (of the four parities) ranged from 5.0 to 19.5 piglets per sow per litter (mean of $11.9 \pm 2.4$ ), regardless of the genotype (Figure 3 ).

The total number of piglets born (TNB), number born alive (NBA), number of mummies (NMUM) or number of stillborn (NSB) piglets per litter did not differ among the various ER-PvuII and RBP4-MspI genotypes when considering either first parity or all four parities (Tables 1, 2 and $3)$. However, analysis of the interaction between genotypes, excluding the first parity, showed that animals carrying the ER-PvuII allele A (genotype $\mathrm{AA}$ or $\mathrm{AB}$ ) and the RBP4-MspI genotype A1 produced more piglets

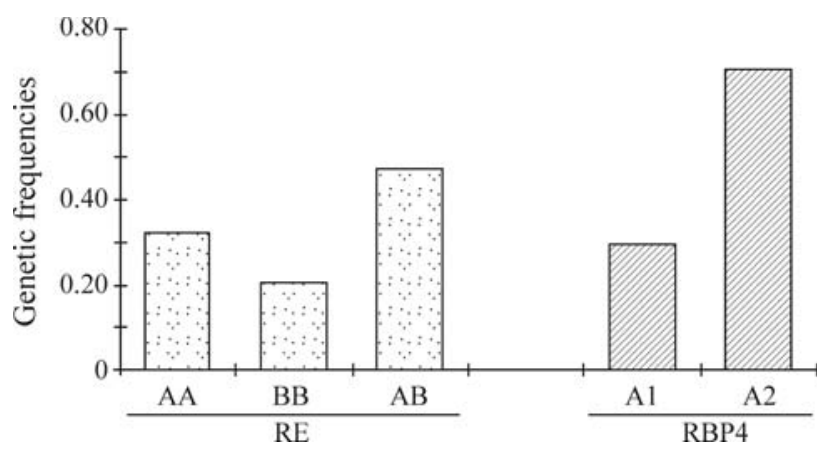

Figure 1 - Genotype frequency of the estrogen receptor and retinolbinding protein 4 gene polymorphisms in sows of a commercial population from Brazil.

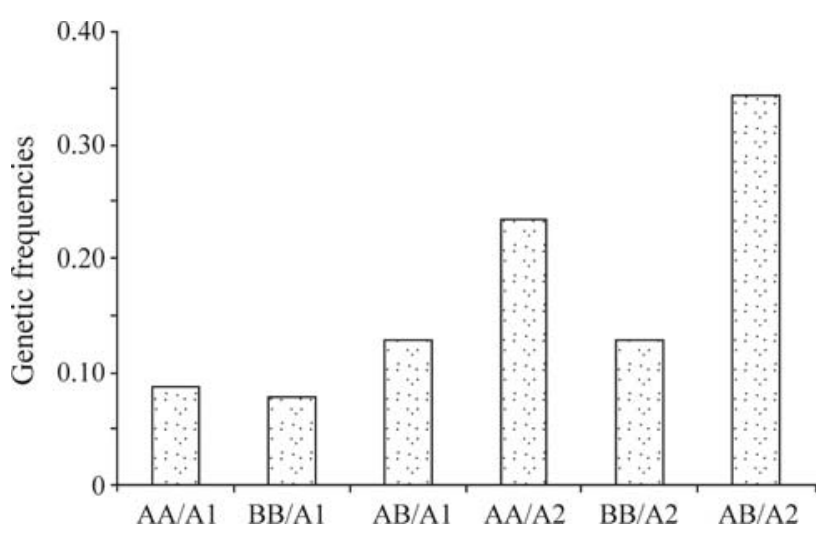

Figure 2 - Frequency of the association between estrogen receptor and retinol-binding protein 4 polymorphism genotypes in sows of a commercial population from Brazil.

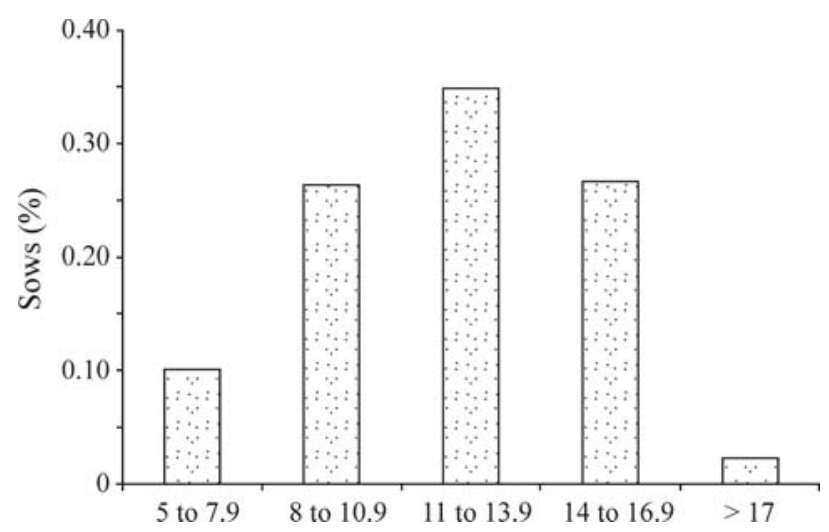

Figure 3 - Distribution of animals according to the mean number of piglets per parity, considering a total of four parities, in sows of a commercial population from Brazil.

$(\mathrm{AA} / \mathrm{A} 1=13.6 \pm 0.5 ; \mathrm{AB} / \mathrm{A} 1=13.6 \pm 0.4)$. Similarly, animals carrying the $E R$-PvuII allele B and the RBP4-MspI genotype A2 also presented high productivity $(\mathrm{BB} / \mathrm{A} 2=13.5 \pm 0.4 ; \mathrm{AB} / \mathrm{A} 2=12.9 \pm 0.3)$. In contrast, the mean litter size was smaller for sows with the $\mathrm{AA} / \mathrm{A} 2$ $(12.2 \pm 0.3)$ and BB/A1 (12.3 \pm 0.6$)$ genotypes compared to the other genotypes $(\mathrm{p}<0.05)$. Thus, the combination of genotypes ER-PvuII and RBP4-MspI resulted in a mean 1.4-fold increase in TNB ( $\mathrm{p}=0.0026)$ and a 0.9 -fold increase in NBA $(p=0.0190)$ per litter for animals with the $\mathrm{AA} / \mathrm{A} 1$ and $\mathrm{AB} / \mathrm{A} 1$ genotypes compared to $\mathrm{AA} / \mathrm{A} 2$ and $\mathrm{BB} / \mathrm{A} 1$ sows. Sows with genotypes $\mathrm{BB} / \mathrm{A} 2$ and $\mathrm{AB} / \mathrm{A} 2$ produced on average $0.9(p=0.0258)$ and $0.8(p=0.0168)$ more TNB and NBA, respectively, than AA/A2 and BB/A1 animals, but did not differ from sows with the AA/A1 and AB/A1 genotypes (Table 4).

\section{Discussion}

The main finding of this study was the interaction between gene polymorphisms ER-PvuII and RBP4-MspI and their influence on prolificacy in pig populations, in which 
Table 1 - Association of estrogen receptor (ER-PvuII) and retinol-binding protein 4 (RBP4-MspI) genotypes with mean number of piglets born alive (NBA), number of mummies (NMUM), number of stillborn piglets (NSB), and total number born (TNB) per litter in the four parities.

\begin{tabular}{lccccc}
\hline Genotype* & Parity $\mathrm{n}$ & NBA (Mean \pm SE) & NMUM $($ Mean \pm SE) & NSB $($ Mean \pm SE) & TNB $($ Mean \pm SE) \\
\hline ER-PvuII & & & & & \\
AA & 258 & $11.5 \pm 0.2$ & $0.2 \pm 0.0$ & $0.8 \pm 0.1$ & $12.5 \pm 0.2$ \\
AB & 390 & $11.8 \pm 0.2$ & $0.3 \pm 0.0$ & $0.7 \pm 0.1$ & $12.8 \pm 0.2$ \\
BB & 169 & $11.7 \pm 0.3$ & $0.2 \pm 0.0$ & $0.8 \pm 0.1$ & $12.7 \pm 0.3$ \\
\hline$R B P 4-$ MspI & & & & \\
A1 & 242 & $11.8 \pm 0.2$ & $0.3 \pm 0.0$ & $0.9 \pm 0.1$ & $12.9 \pm 0.3$ \\
A2 & 575 & $11.6 \pm 0.1$ & $0.3 \pm 0.0$ & $0.7 \pm 0.0$ & $12.6 \pm 0.2$ \\
\hline
\end{tabular}

*Animals were classified according to genotype into AA, BB (homozygous) or AB (heterozygous) for ER-PvuII and A1 or A2 for RBP4-MspI (see Material and Methods for details).

Table 2 - Association between estrogen receptor (ER-PvuII) genotypes and mean number of piglets born alive (NBA), number of mummies (NMUM), number of stillborn piglets (NSB), and total number born (TNB) per litter at first parity and for all other parities.

\begin{tabular}{lccccc}
\hline Genotype* & $\mathrm{n}$ & NBA (Mean \pm SE) & NMUM (Mean \pm SE) & NSB $($ Mean \pm SE) & TNB $($ Mean \pm SE) \\
\hline First farrowing & & & & & \\
AA & 70 & $11.3 \pm 0.4$ & $0.6 \pm 0.1$ & $0.3 \pm 0.1$ & $12.2 \pm 0.4$ \\
AB & 103 & $11.0 \pm 0.3$ & $0.7 \pm 0.1$ & $0.3 \pm 0.1$ & $12.1 \pm 0.3$ \\
BB & 45 & $11.0 \pm 0.5$ & $0.6 \pm 0.1$ & $0.1 \pm 0.0$ & $11.7 \pm 0.5$ \\
\hline 2nd, 3rd and 4th farrowings & & & & \\
AA & 188 & $11.5 \pm 0.2$ & $0.8 \pm 0.1$ & $0.2 \pm 0.0$ & $12.6 \pm 0.3$ \\
AB & 287 & $12.0 \pm 0.2$ & $0.7 \pm 0.1$ & $0.3 \pm 0.0$ & $13.1 \pm 0.2$ \\
BB & 124 & $12.0 \pm 0.3$ & $0.9 \pm 0.1$ & $0.3 \pm 0.1$ & $13.1 \pm 0.3$ \\
\hline
\end{tabular}

Animals were classified according to genotype into AA, BB (homozygous) or AB (heterozygous) for the ER-PvuII system.

Table 3 - Association between retinol-binding protein 4 (RBP4-MspI) genotypes and mean number of piglets born alive (NBA), number of mummies (NMUM), number of stillborn piglets (NSB), and total number born (TNB) per litter at first parity and for all other parities.

\begin{tabular}{lccccc}
\hline Genotype* & $\mathrm{n}$ & NBA (Mean \pm SE) & NMUM (Mean \pm SE) & NSB (Mean \pm SE) & TNB $($ Mean \pm SE) \\
\hline First farrowing & & & & & \\
A1 & 64 & $11.3 \pm 0.4$ & $0.7 \pm 0.1$ & $0.3 \pm 0.1$ & $12.3 \pm 0.4$ \\
A2 & 154 & $11.0 \pm 0.3$ & $0.7 \pm 0.1$ & $0.2 \pm 0.0$ & $11.9 \pm 0.3$ \\
\hline 2nd, 3rd and 4th farrowings & & & & \\
A1 & 178 & $12.0 \pm 0.3$ & $1.0 \pm 0.1$ & $0.3 \pm 0.1$ & $13.3 \pm 0.3$ \\
A2 & 421 & $11.8 \pm 0.2$ & $0.7 \pm 0.1$ & $0.3 \pm 0.0$ & $12.8 \pm 0.2$ \\
\hline
\end{tabular}

*Animals were classified according to genotype into A1 or A2 for RBP4-MspI (see Material and Methods for details).

the favorable genotypes (ER-PvuII allele A and RBP4MspI genotype A1) were not related to TNB and NBA per litter when analyzed separately. ER-PvuII allele B (Rothschild et al., 1996; Short et al., 1997) and RBP4-MspI genotype A1 have been associated with increased prolificacy in pig populations. However, some studies failed to demonstrate association between these polymorphisms and prolificacy (Drogemuller et al., 2001; Isler et al., 2002), which might be due to possible different linkage phases between the marker alleles and the mutation responsible for the effect in different lines, notably in the case of the ER-PvuII polymorphism that is located on an intron.

In the population studied, animals carrying the $E R$ PvuII allele B were only more prolific when associated with the RBP4-MspI genotype A2, whereas sows with the $E R$-PvuII allele A presented a larger mean TNB and NBA when associated with the RBP4-MspI genotype A1. The effect of this interaction between genotypes $E R$-PvuII and $R B P 4-M s p I$ on the increase in prolificacy demonstrates the need for the establishment of various molecular markers for 
Table 4 - Association of combinations of estrogen receptor (ER-PvuII) and retinol-binding protein 4 (RBP4-MspI) genotypes with mean number of piglets born alive (NBA), number of mummies (NMUM), number of stillborn piglets (NSB), and total number born (TNB) per litter in the four parities.

\begin{tabular}{|c|c|c|c|c|c|}
\hline Genotype* & $\mathrm{n}$ & NBA $($ Mean \pm SE) & $\operatorname{NMUM}($ Mean \pm SE $)$ & NSB $($ Mean \pm SE) & $\mathrm{TNB}($ Mean $\pm \mathrm{SE})$ \\
\hline \multicolumn{6}{|c|}{ First farrowing } \\
\hline $\mathrm{A} / \mathrm{A} 1$ & 47 & $11.3 \pm 0.5^{\mathrm{a}}$ & $0.4 \pm 0.1$ & $0.8 \pm 0.1$ & $12.5 \pm 0.4^{\mathrm{a}}$ \\
\hline AA2-BB1 & 68 & $11.0 \pm 0.4^{\mathrm{a}}$ & $0.2 \pm 0.1$ & $0.5 \pm 0.1$ & $11.7 \pm 0.4^{\mathrm{a}}$ \\
\hline $\mathrm{B} / \mathrm{A} 2 *$ & 103 & $11.0 \pm 0.3^{\mathrm{a}}$ & $0.2 \pm 0.1$ & $0.8 \pm 0.1$ & $12.0 \pm 0.3^{\mathrm{a}}$ \\
\hline \multicolumn{6}{|c|}{$2 \mathrm{nd}, 3 \mathrm{rd}$ and 4 th farrowings } \\
\hline $\mathrm{A} / \mathrm{A} 1$ & 133 & $12.2 \pm 0.3^{\mathrm{a}}$ & $0.3 \pm 0.1$ & $1.1 \pm 0.1$ & $13.6 \pm 0.3^{\mathrm{a}}$ \\
\hline AA2-BB1 & 181 & $11.3 \pm 0.3^{\mathrm{b}}$ & $0.2 \pm 0.0$ & $0.8 \pm 0.1$ & $12.2 \pm 0.3^{\mathrm{b}}$ \\
\hline $\mathrm{B} / \mathrm{A} 2$ & 285 & $12.1 \pm 0.2^{\mathrm{a}}$ & $0.3 \pm 0.0$ & $0.7 \pm 0.1$ & $13.1 \pm 0.2^{\mathrm{a}}$ \\
\hline
\end{tabular}

*Animals were classified according to genotype into AA, $\mathrm{BB}$ (homozygous) or $\mathrm{AB}$ (heterozygous) for $E R$-PvuII and $\mathrm{A} 1$ or $\mathrm{A} 2$ for $R B P 4-\mathrm{MspI}$ (see Material and Methods for details). $\mathrm{A} / \mathrm{A} 1=$ animals carrying $E R$-PvuII allele $\mathrm{A}$ (genotype $\mathrm{AA}$ or $\mathrm{AB}$ ) and $R B P 4-\mathrm{Mspl}$ genotype $\mathrm{A} 1 ; \mathrm{AA} 2-\mathrm{BB} 1=$ animals homozygous for $E R$-PvuII (genotype $\mathrm{AA}$ or $\mathrm{BB}$ ) and $\mathrm{A} 1$ or $\mathrm{A} 2 R B P 4-\mathrm{MspI}$ genotype; $\mathrm{B} / \mathrm{A} 2$ = animals carrying $E R$-PvuII allele $\mathrm{B}$ and $R B P 4$-MspI genotype A2.

${ }^{\mathrm{ab}}$ In the same column values with different letters are significantly different at $(\mathrm{p}<0.05)$.

the selection of productive traits of low heritability that involve candidate genes related to the trait to be selected. In the case of selection based on TNB and NBA, several factors should be taken into account, such as the number of ovulations, gamete and embryo viability, body and nutritional condition, uterine capacity, and competence for pregnancy recognition (Flint et al., 1983; Wu et al., 1989; Chen and Dziuk, 1993; Soede et al., 1994; Ferguson et al., 2003; Soboleva et al., 2004). The relevance of ER and RBP4 in the physiology of early pregnancy led to the choice of these genes as candidates for the study of the association with prolificacy in pigs. Estrogen and its receptors are involved in the regulation of hormones which are responsible for the control of follicular dynamics (Soboleva et al., 2004), pregnancy recognition (Flint et al., 1983), and reduction in embryo mortality (Soede et al., 1994). On the other hand, retinol and its binding proteins play a crucial role in embryo and fetal development, with both excess retinol, which exhibits teratogenic effects, and deficient retinol exerting an influence (Lefebvre et al., 2005). Embryo loss has been shown to be reduced and litter size and piglet birth weight to be increased in pregnant sows injected with $\beta$-carotene or vitamin A (Coffey and Britt, 1993; Chew, 1996). In addition, retinol and its binding proteins are probably involved in the reduction of embryo mortality. Increased expression of the RBP4 gene in the endometrium is observed in sows between day 10 and day 12 of gestation, demonstrating the importance of vitamin A and its transport proteins in the establishment of pregnancy (Harney et al., 1993).

The allele and genotype frequencies observed in the present sample suggest that these markers were not used as a tool in the selection of the animals of this population. $E R$-PvuII allele $\mathrm{B}$ is present in some highly prolific pig breeds such as Meishan and Large White/Yorkshire pigs (Rothschild et al., 1996). The population studied is a commercial line derived from the crossing of various breeds.
This population showed a high frequency of $E R$-PvuII allele B (0.44), and one third of the animals presented RBP4MspI genotype A1 (0.29). Since only two RBP4-MspI genotypes were considered, similar allele frequencies were obtained for ER-PvuII and RBP4-MspI. This fact also demonstrates that animals of the commercial line studied were influenced by prolific ancestors, such as pigs of Chinese breeds used in the crosses that gave origin to the breed.

Since the animals studied were not chosen randomly but based on the history of the last four parities, a distribution according to the mean number of piglets per litter was observed, with the number of piglets ranging from 5.0 to 19.5 in the four farrowings (total of 817 farrowings). The objective of this sampling was to include representative animals of different productivity classes, in order to detect an association or an interaction between genotypes and TNB and NBA.

The interaction between ER-PvuII and RBP4-MspI alleles might be more efficient in the selection of more prolific animals than each molecular marker alone. Both the sows carrying the ER-PvuII allele A and the RBP4-MspI genotype $\mathrm{A} 1$ and those with the ER-PvuII allele B and the $R B P 4-M s p I$ genotype $\mathrm{A} 2$ produce more piglets and more live piglets per litter.

\section{Acknowledgments}

We thank Conselho Nacional de Desenvolvimento Científico e Tecnológico (CNPq) for the financial support provided.

\section{References}

Chen ZY and Dziuk PJ (1993) Influence of initial length of uterus per embryo and gestation stage on prenatal survival, development, and sex ratio in the pig. J Anim Sci 71:1895-1901.

Chew BP (1996) Importance of antioxidant vitamins in immunity and health in animals. Anim Feed Sci Technol 59:103-114. 
Coffey MT and Britt JH (1993) Enhancement of sow reproductive performance by beta-carotene or vitamin A. J Anim Sci 71:1198-1202.

Dekkers JCM (2004) Commercial application of marker- and gene-assisted selection in livestock: Strategies and lessons. J Anim Sci 82:E313-E328.

Drogemuller C, Hamann H and Distl O (2001) Candidate gene markers for litter size in different German pig lines. J Anim Sci 79:2565-2570.

Ferguson EM, Ashworth CJ, Edwards SA, Hawkins N, Hepburn $\mathrm{N}$ and Hunter MG (2003) Effect of different nutritional regimens before ovulation on plasma concentrations of metabolic and reproductive hormones and oocyte maturation in gilts. J Reprod Fertil 126:61-71.

Flint APF, Burton RD, Gadsby JE, Heap RB and Sheldrick EL (1983) Embryonic steroid synthesis and luteal oxytocin production: Controlling mechanisms for the maternal recognition of pregnancy. J Steroid Biochem 19:973-978.

Gibson JP, Jiang ZH, Robinson JAB, Archibald AL and Haley CS (2002) No detectable association of the ESR PvuII mutation with sow productivity in a Meishan $\mathrm{x}$ Large White F2 population. Anim Genet 33:448-450.

Harney JP, Ott TL, Geisert RD and Bazer FW (1993) Retinolbinding protein gene expression in cyclic and pregnant endometrium of pigs, sheep, and cattle. Biol Reprod 49:1066-1073.

Isler BJ, Irvin KM, Neal SM, Moeller SJ and Davis ME (2002) Examination of the relationship between the estrogen receptor gene and reproductive traits in swine. J Anim Sci 80:2334-2339.

Lahiri DK and Nurnberger JI (1991) A rapid non-enzymatic method for the preparation of HMW DNA from blood for RFLP studies. Nucleic Acids Res 19:5444.

Lefebvre P, Martin PJ, Flajollet S, Dedieu S, Billaut X and Lefebvre B (2005) Transcriptional activities of retinoic acid receptors. In: Litwack G (ed) Vitamins \& Hormones. Volume 70. Academic Press, Burlington, pp 199-264.

Lewis PO and Zaikin D (2001) Genetic data analysis: Computer program for the analysis of allelic data. Available at http://lewis.eeb.uconn.edu/lewishome/software.html.

Rothschild M, Jacobson C, Vaske DA, Tuggle CK, Short TH, Sasaki S, Eckardt GR and McLaren DG (1994) A major gene for litter size in pigs. Proc 5th World Congr Genet Appl Livestock Prod 21:225-228.

Rothschild M, Jacobson C, Vaske D, Tuggle C, Wang L, Short T, Eckardt G, Sasaki S, Vincent A, McLaren D, et al. (1996) The estrogen receptor locus is associated with a major gene influencing litter size in pigs. Proc Natl Acad Sci USA 93:201-205

Rothschild MF, Messer L, Day A, Wales R, Short T, Southwood $\mathrm{O}$ and Plastow $\mathrm{G}$ (2000) Investigation of the retinol-binding protein 4 (RBP4) gene as a candidate gene for increased litter size in pigs. Mamm Genome 11:75-77.

Short TH, Rothschild MF, Southwood OI, McLaren DG, de Vries A, van der Steen H, Eckardt GR, Tuggle CK, Helm J, Vaske DA, et al. (1997) Effect of the estrogen receptor locus on reproduction and production traits in four commercial pig lines. J Anim Sci 75:3138-3142.

Soboleva TK, Pleasants AB, van Rens BTTM, van der Lende T and Peterson AJ (2004) A dynamic model for ovulation rate reveals an effect of the estrogen receptor genotype on ovarian follicular development in the pig. J Anim Sci 82:23292332.

Soede NM, Helmond FA and Kemp B (1994) Periovulatory profiles of oestradiol, $\mathrm{LH}$ and progesterone in relation to oestrus and embryo mortality in multiparous sows using transrectal ultrasonography to detect ovulation. J Reprod Fertil 101:633-641.

Varona L, Vidal O, Quintanilla R, Gil M, Sanchez A, Folch JM, Hortos M, Rius MA, Amills M and Noguera JL (2005) Bayesian analysis of quantitative trait loci for boar taint in a Landrace outbred population. J Anim Sci 83:301-307.

Vidal O, Noguera JL, Amills M, Varona L, Gil M, Jimenez N, Davalos G, Folch JM and Sanchez A (2005) Identification of carcass and meat quality quantitative trait loci in a Landrace pig population selected for growth and leanness. J Anim Sci $83: 293-300$

Wu MC, Chen ZY, Jarrell VL and Dziuk PJ (1989) Effect of initial length of uterus per embryo on fetal survival and development in the pig. J Anim Sci 67:1767-1772.

Associate Editor: Pedro Franklin Barbosa

License information: This is an open-access article distributed under the terms of the Creative Commons Attribution License, which permits unrestricted use, distribution, and reproduction in any medium, provided the original work is properly cited. 